\title{
The Effect of Teaching Concept Mapping in Reading on EFL Learners' Self-Regulation
}

\author{
Mania Nosratinia ${ }^{1}$, Zeynab Mirsafaee ${ }^{2}$, Hossein Shakeri $^{3}$ \\ 1, 2, 3 (English Department, Faculty of Foreign Languages/ Islamic Azad University at Central Tehran, Iran)
}

\begin{abstract}
The present study is an attempt to investigate the effect of teaching concept mapping as a learning strategy in reading on Iranian EFL learners' self-regulation. To fulfill the purpose of this study, a group of 90 female learners attending Intermediate courses of Zarrin Language School took a sample PET as a proficiency test, 60 of them were selected as homogenous learners and were randomly assigned to experimental and control groups. Then, all of the students in two groups completed the "Motivated Strategies for Learning Questionnaire" (MSLQ) as a pretest. The teacher taught the same content based on "American Head Way 4" throughout a 16-session to two groups. The only difference was that the experimental group received concept mapping strategy training. At the end of the training, all the students in two groups again completed the selfregulation questionnaire (MSLQ) as post-test in order to assess the learners' self-regulation. The results of the independent $t$-test indicate that there is a significant difference between experimental and control groups' mean scores on the post-test of self-regulation which means that the experimental group outperformed the control group on the post-test of self-regulation after receiving concept mapping strategy.
\end{abstract}

Keywords: concept mapping, reading comprehension, self-regulation

\section{Introduction}

Reading as one of the most necessary skills for daily life, is a process involving the activation of relevant knowledge and related language skills to accomplish an exchange of information from one person to another through a text. It requires that the readers focus attention on the reading materials and integrate previously acquired knowledge and skills to comprehend what someone else has written (Chastain, 1988) ${ }^{[1]}$.

Not only in daily life, but also in learning a foreign language, reading is an essential skill to acquire knowledge and to exchange information (Huang, 2005) ${ }^{[2]}$. However, effective reading is not something that every individual learns to do (Nunan, 1999) ${ }^{[3]}$. In this regard and in order to improve learners' reading abilities, effective learning strategies and assistant tools should be carefully taken into account. Park $\left(1995\right.$, p. 35) ${ }^{[4]}$ defines learning strategies as "the mental activities that people use when they study to help themselves acquire, organize, or remember incoming knowledge more efficiently". In a classification, O'Malley, Chamot, StewnerManzanares, Kupper, and Russo (1985) ${ }^{[5]}$ categorized learning strategies under three main groups:

1. Metacognitive strategies (e.g. planning for learning, thinking about the learning process as it is taking place, monitoring of one's production or comprehension, and evaluating learning after an activity is completed);

2. Cognitive strategies (e.g. repeating, translation, grouping, note taking, deducting, imagery, auditory representation, key word, contextualization, elaboration, transfer); and

3. Socioaffective strategies (e.g. social-mediating activity and transacting with others).

Among these strategies, metacognitive strategies are considered as the most essential in developing learners' skills (Anderson, 1991) ${ }^{[6]}$. Having the same ground, O'Malley et al. (1985) ${ }^{[5]}$ believe that without metacognitive strategies learners have no direction or ability to monitor their progress, accomplishments, and future learning directions. On the other hand, learners who have developed their metacognitive awareness are likely to become more self-regulated and autonomous language learners (Hauck, 2005) ${ }^{[7]}$.

Among the metacognitive strategies, there are a number of strategies that can help students become more sophisticated learners, and thus better able to learn over the long run. These strategies include concept mapping, organizing, note taking, identifying important information, and summarizing (Pressley, 1982; Weinstein, 1988) ${ }^{[8][9]}$.

Concept maps have been described as "metacognitive strategies" (Mintzes, Wandersee, \& Novak, 1997) ${ }^{[10]}$ that encourage students to think reflectively about what they know through the visual representation of concept meanings and relationships. The process of creating and modifying a concept map involves making decisions about the different ways that concepts are related to one another, leading the individual to reflect on prior knowledge as it relates to new material (McAleese, 1998) ${ }^{[11]}$, as well as engaging in control processes of planning, monitoring progress, and evaluating goal attainment as the map is constructed (Brown, 1987) ${ }^{[12]}$.

Concept mapping is a strategy for representing the interrelationships among concepts in an integrated, hierarchical manner. Concept maps should not simply list information from text randomly, or even in a linear 
fashion, rather, concept maps should depict the structure of knowledge in propositional statements that illustrate the relationships among the concepts in a map (Novak, 1981) ${ }^{[13]}$.

Additionally, there are some evidences that concept mapping is a useful strategy for ESL (English as a second language) students (Block, 1986; Carrell, Pharis, \& Liberto, 1989; Kamhi-Stein, 1993; Koumy \& Salam, $1999)^{[14][15][16][17]}$. Using concept mapping facilitates meaningful learning because concepts are seen not as isolated entities, but as existing in a network of relationships (Heinze-Fry \& Novak, 1990) ${ }^{[18]}$. Other studies indicate that concept mapping is an effective learning strategy in a variety of domains, such as reading. It can enhance learners' reading comprehension to a great extent (Cassata-Widera, 2008; Chimielewski \& Dansereaw, 1998; Griffin, Malone, \& Kameenui, 1995; Liou, 2006; Robinson, Katayama, \& Fan, 1996; Zittle, 2005) ${ }^{[19]}{ }^{[20]}$ [21] [22] [23] [24].

Moreover, Cubukcu (2009) ${ }^{[25]}$, Ryan and Deci (2006) ${ }^{[26]}$, Talebinezhad and Mousapour Negari $(2009)^{[27]}$ in their studies show that the benefits of concept mapping may also include positive effects on achievement-related variables such as academic self-regulation and self-efficacy.

The importance of self-regulation in learning has been of interest and concern to educators, researchers, and theorists since Albert Bandura's seminal work on social cognitive theory $(1980){ }^{[28]}$. Students' ability to control their learning or "self-regulation" according to Zimmerman (1986) ${ }^{[29]}$ refers to the degree at which individuals become metacognitively, motivationally, and behaviorally active participants in their own learning processes.

Pintrich $(2000)^{[30]}$ defines self-regulation as "an active, constructive process whereby learners set goals for their learning and then attempt to monitor, regulate, and control their cognition, motivation, and behavior, guided by and constrained by their goals and the contextual features in the environment" (p. 453). It is also believed that the major cause of failure in improving L2 skills effectively is the lack of self-regulation (Zimmerman, 1986) ${ }^{[29]}$.

Self-regulation comprises a variety of processes such as setting goals for learning; attending to and concentrating on instruction; using effective strategies to organize, code, and rehearse information to be remembered; establishing a productive work environment; using resources effectively; monitoring performance; managing time effectively; seeking assistance when needed; holding positive beliefs about one's capabilities, the value of learning, the factors influencing learning and the anticipated outcomes of actions; and experiencing pride and satisfaction with one's efforts (Zimmerman, 2001) ${ }^{[31]}$.

All together and regarding the point that learners can learn how to regulate their cognitive activities, using strategies and learning process (Oxford, 1990) ${ }^{[32]}$, it seems essential to find the most effective ways to motivate EFL learners to become autonomous and self-regulated in their learning process. In line with the same need and necessity, this study is an attempt to investigate the effectiveness of teaching concept mapping as a learning strategy in reading on Iranian EFL learners' self-regulation. Hence, the following research question was raised to be investigated:

Q1. Does teaching concept mapping strategy in reading have any statistically significant effect on EFL learners' self- regulation?

\subsection{Participants}

\section{Methodology}

To accomplish the objectives of this study, 90 female students with the age range of 20-30 were nonrandomly selected from intermediate level classes at Zarrin Language School in Esfahan, Iran. Out of this sample and through a piloted Preliminary English Test (PET) 60 of them whose scores fell between one standard deviation above and one standard deviation below the mean were selected. The homogenized participants were then randomly assigned into experimental and control groups each containing 30 students.

It is worth mentioning that a group of 30 students with very much similar language proficiency level and characteristics to the target sample participated in piloting the PET language proficiency test.

\subsection{Instrumentation}

\subsubsection{Preliminary English Test (PET)}

In order to homogenize the language proficiency of the participants, the researchers administered the Preliminary English Test (PET), developed in 2010, as one of the Cambridge ESOL standardized proficiency tests which is used for people who can use every day written English at an Intermediate level. It covers the four main language skills: reading, writing, listening and speaking, using material from real life situation.

Reading section has five parts and 35 reading comprehension questions while writing section consist of three parts and seven questions. The candidates are expected to comprehend the main points from journals, signs, newspapers and be able to use vocabulary and structures correctly in one hour and 30 minutes. In the listening section which lasts 30 minutes, the participants are supposed to follow and understand a range of spoken materials including announcements and discussion about everyday life. This section includes four parts 
with 25 questions. In the speaking section which includes four parts and takes 10-12 minutes, the candidates have to show their spoken English by taking part in conversation, asking and answering questions, and talking freely about their likes and dislikes.

The test was first piloted among 30 other learners demonstrating almost the same characteristics as the target sample. After item analysis two items were found to be malfunctioning and hence were discarded from the test. The reliability index of the instrument was also computed through Cronbach alpha at .901 and .936 before and after the deletion of two malfunctioning items respectively.

\subsubsection{Rating Scale of the PET Writing}

The rating scale used to rate the writing section of the PET was the one provided by Cambridge under the name of General Mark Schemes for Writing. The rating was done on the basis of the criteria stated in the rating scale including the rating scale of $0-5$.

\subsubsection{Rating Scale of the PET Speaking}

The rating scale used to rate the oral proficiency of the participants was the predetermined official Cambridge General Mark Schemes for Speaking. The rating was done on the basis of the criteria stated in the rating scale including the range of scores from 0 to 5 .

\subsubsection{Motivated Strategies for Learning Questionnaire (MSLQ)}

All of the students in two groups (experimental \& control) completed the Motivated Strategies for Learning Questionnaire (MSLQ) (Pintrich, Smith, Garcia, \& McKeachie, 1991) ${ }^{[33]}$ as a pretest and post-test in order to assess the learners' self-regulation before and after treatment. The Original form of MSLQ consists of 81 Likert-scale items divided into two sections; motivation (31 items, 6 subscales) and learning strategies (50 items, 9 subscales). Table 1 presents different parts of the MSLQ questionnaire.

Table 1: MSLQ Scales and Subscales (Pintrich, et al., 1991) ${ }^{[33]}(\mathrm{R}=$ Reversed Item)

\begin{tabular}{|c|c|c|c|}
\hline Scales & Dimensions & Subscales & Items \\
\hline \multirow{3}{*}{ Motivation } & $\begin{array}{l}\text { Expectancy } \\
\text { Components }\end{array}$ & $\begin{array}{l}\text { Control Beliefs } \\
\text { Self-Efficacy }\end{array}$ & $\begin{array}{l}2,9,18,25 \\
5,6,12,15,20,21,29,31\end{array}$ \\
\hline & $\begin{array}{l}\text { Value } \\
\text { Components }\end{array}$ & $\begin{array}{l}\text { Intrinsic Goals } \\
\text { Extrinsic Goals } \\
\text { Task Value }\end{array}$ & $\begin{array}{l}1,16,22,24 \\
7,11,13,30 \\
4,10,17,23,26,27\end{array}$ \\
\hline & Affective Components & Test Anxiety & $3,8,14,19,28$ \\
\hline \multirow{3}{*}{ Learning Strategies } & $\begin{array}{l}\text { Cognitive } \\
\text { Strategies }\end{array}$ & $\begin{array}{l}\text { Rehearsal } \\
\text { Elaboration } \\
\text { Organization } \\
\text { Critical thinking }\end{array}$ & $\begin{array}{l}39,46,59,72 \\
53,62,64,67,69,81 \\
32,42,49,63 \\
38,47,51,66,71\end{array}$ \\
\hline & $\begin{array}{l}\text { Metacognitive } \\
\text { Control Strategies }\end{array}$ & Self-Regulation & $\begin{array}{l}33 \mathrm{R}, 36,41,44,54,55,56,57 \mathrm{R} \\
, 61,76,78,79\end{array}$ \\
\hline & $\begin{array}{l}\text { Resource management } \\
\text { strategies }\end{array}$ & $\begin{array}{l}\text { Time and Place of } \\
\text { Study } \\
\text { Effort Regulation } \\
\text { Peer Learning } \\
\text { Help Seeking }\end{array}$ & $\begin{array}{l}35,43,52 \mathrm{R}, 65,70,73,77 \mathrm{R}, 80 \mathrm{R} \\
37 \mathrm{R}, 48,60 \mathrm{R}, 74 \\
34,45,50 \\
40 \mathrm{R}, 58,68,75\end{array}$ \\
\hline
\end{tabular}

The participants were instructed to respond to the items on a 7 point Likert Scale $(7=$ Very true of me, $6=$ True of me, 5= Mostly true of me, $4=$ About halfway true of me, $3=$ Slightly true of me, $2=$ Somehow true of me, $1=$ Not at all true of me) in terms of their behaviors in their English classes. According to Pintrich, et al. $(1991)^{[33]}$, the MSLQ scales are designed to be modular and can be used to fit the needs of researchers. Therefore, based on the requirements of this study, the researchers selected eight subscales including task value (6 items), control of learning beliefs (4 items), elaboration (6 items), metacognitive self-regulation (12 items), time and study environment ( 8 items), effort regulation (4 items), help seeking (4 items), and peer learning (3 items). The adapted version of MSLQ used in this study consisted of a total number of 47 items. There were eight items that had to be reverse-scaled including 17, 24, 31, 35, 36, 37, 39, and 44 (Table 1). For the reversed items the values are $(1=7,2=6,3=5,4=4,5=3,6=2, \& 7=1)$. In this regard, the result could vary from 47 to 329 , and the higher the mark, the more self-regulated was the participant. The respondents were supposed to answer the questions in 25 minutes.

For the questionnaire, scale reliabilities are robust and confirmatory factor analyses demonstrated good factor structure (D'Apollonia, Galley, \& Simpson, 2001) ${ }^{[34]}$. In addition, the instrument shows reasonable predictive validity to the actual course performance of students (Barker \& Olsen, 2002; Garcia \& Pintrich, 1994) [35] [36]. 
This instrument is originally written in English. However, to avoid any linguistic confusion and misunderstanding, the Persian translated version of the questionnaire by Navidi (2003) ${ }^{[37]}$ was used. The test was piloted and its reliability was calculated by Cronbach Alpha formula at 0.81 .

\subsubsection{Hand Out of Concept Mapping}

The participants in experimental group practiced the application of concept mapping in reading. They were provided with handouts that included definition of concept mapping, different uses, advantages, detailed explanation on different ways to construct them, and examples of concept maps based on Harris and Graham procedure of strategy instruction $(1996)^{[38]}$. They were required to complete the incomplete maps (based on the "fill in the Map Model" of concept mapping) or to draw concept maps of their own (based on the "Hierarchical Model" of concept mapping).

\subsubsection{American Head Way 4}

All of the subjects in this research, received instruction based on "American Head Way 4", by Liz and John Soars $(2005)^{[39]}$ which consists of 12 units. The main purpose of this book is to integrate speaking, grammar, vocabulary, pronunciation, listening, reading and writing. The book is accompanied with: a student book with self-study audio $\mathrm{CD}$, workbook, teacher's edition, and class audio $\mathrm{CD}$.

As mentioned before, this study was conducted in Zarrin Language School. In this language school four units of "American Head Way 4" were taught in each of the three terms of Intermediate level. Each unit has 3 texts followed by multiple choice items, fill in the blank items, and descriptive questions to be answered by learners. For the purpose of this study, all the texts of the last four units $(9,10,11, \& 12)$ were taught by one of the researchers.

\subsection{Procedure}

To accomplish the purpose of the study the following procedure was pursued:

Prior to the main administration, the PET test was standardized by piloting it among a group of 30 students with almost similar characteristics of the representative sample in two different sessions (one session for reading, writing, and listening parts and another session for speaking part).

Then, the three characteristics of individual items (Item Facility, Item Discrimination, \& Choice Distribution) were calculated in order to omit the malfunctioning items. The Cronbach alpha formula was employed for calculating the reliability of the test's scores gained by the participants.

The writing and speaking parts of the PET were rated by two raters (two of the researchers) according to the rating scales provided by Cambridge General Mark Schemes for Writing and Speaking. The inter-rater reliabilities were calculated on the basis of the ratings done by both raters for the pilot test of PET. Since there was an acceptable consistency between the two raters, the researchers went through the same procedure for the main participants.

The already piloted PET was given to 90 female intermediate level students of Zarrin Language School through which 60 students whose scores fall between one standard deviation above and below the mean were chosen.

The 60 subjects were divided randomly into experimental and control groups. Then, all of the students in two groups completed the self-regulation questionnaire (MSLQ) (Pintrich, et al., 1991) ${ }^{[33]}$ in order to make sure that there was no significant difference between the two groups regarding this variable before the treatment.

Next, all of the participants were taught using the same material and they received the same amount of instruction. The only difference lay in the teaching of concept mapping strategies which was included in the experimental group. Both classes comprising the two groups were instructed by the same teacher (one of the researchers). The course consisted of 16 sessions of 90 minutes spanning over a period of approximately six weeks.

\subsubsection{Experimental Group}

The students in experimental group received the instruction for concept mapping strategy. The strategy being taught was based on Harris and Graham procedure of strategy instruction (1996) ${ }^{[38]}$. The procedure consists of five stages:

(1) Strategy description;

(2) Discussion of goals and purposes;

(3) Modeling of the strategy;

(4) Student mastery of strategy; \&

(5) Guided practice and feedback.

The descriptions of the above-mentioned stages are as follows: 
1. Strategy description. As an introduction, students were told that they were going to learn about the strategy of concept mapping. Concept mapping was described as a strategy that could be used to categorize information in a graphic form through drawing.

2. Discussion of goals and purpose of strategy. Concept mapping is described as a strategy that could help learners with vocabulary development and reading comprehension.

For the purpose of this study, the teacher especially discussed about the significance and benefits of using the concept mapping strategy in reading comprehension. Students were asked two questions:

(1) How do you think the strategy of concept mapping might help you to read and comprehend better?

(2) How could this strategy help you with different types of reading comprehension?

To reinforce the students' participation as collaborators in the learning process, their generated goals and purposes were written on the white board.

3. Modeling the strategy. In this stage the step-by-step instruction for creating a concept map was described. Step 1:

- Introduce a concept (from the reading passage) that is familiar to all the students, such as "car", "trip" or "food".

Step 2:

- Have the students write down 10 other concepts that they associate with this main concept (i.e., for food, "vegetables", "meat", "cereal", "milk", "steak", "carrots", etc.). Step 3:

- Ask the students to rank the 10 concepts from "most general and inclusive" to "least general and inclusive" or from "most important" to "least important". Step 4:

- Tell the students to write the "most general" or "most important" concept near the top of paper. Have them enclose this super ordinate concept in a box or oval.

Step 5:

- Explain that you want them to connect concepts from their list, one pair at a time, with directional links; and most importantly, to label the linking lines

[e.g., Carrots $\rightarrow$ vitamin A (linking word is, "contain"]

OR

[Meat $\rightarrow$ iron (linking word is, "is a good source of")]

Continue this process until all concepts appear on the map.

Step 6:

- Give the students enough time (10-20 minutes). Encourage them to include a lot of branching and many levels of hierarchy. Put special emphasis on cross-linking concepts in one area of the map with those in other areas. Suggest that they may add as many additional concepts as they wish. Remind them that the boxes or ovals should contain only one or two words.

Step 7:

- Walk around the room as the students construct their maps. Be supportive but not directive. Remind the students that a concept map is a distinctive representation of their understanding, and that individual components on their maps may or may not be scientifically accurate, but there is a large set of ways to organize and represent what they know. Encourage creativity and stress that there are no one "correct" answer.

Step 8:

- Select several students to show their maps to their classmates. Focus attention on appropriate connections between concepts. Remind students that concept maps may be a very helpful way to study; they can be used to condense the reading text into a summary of what the author presents.

Step 9:

- Collect the students' concept maps and review them, but don't grade them. You may want to suggest ways the maps could be improved.

Step 10:

- Return the maps to the students and suggest that they rethink some of their ideas. The teacher can use different colored pencils for each of the iteration; so, students may depict and emphasize how their ideas change over time. The same map may be used for several class periods, and students may be encouraged to add to, delete, reorganize or even begin a new whenever they need to do so.

4. Student mastery of strategy. During this stage, students rehearsed and memorized the sequence of activities for concept map construction.

5. Guided practice and Feedback. In this stage, the teacher provides the students with feedback on students' performance. 
It should be mentioned that, due to the students' unfamiliarity with the strategy of concept mapping, in the three first sessions the teacher using the approach of "expert-constructed concept maps", explains some complete forms of concept maps. Next, the researcher provided the students with uncompleted forms of concept mapping while the learners has to complete them using "Fill in the Map Model". Finally the learners were required to construct concept maps based on the "Hierarchy Model of Concept Mapping" and the abovementioned procedures.

\subsubsection{Control Group}

The control group received a common teaching procedure of Zarrin Language School, which was not concerned with teaching strategies, as follows:

- The teacher reads the texts.

- Students should guess the meaning of unfamiliar words using contextual clues.

- If they cannot guess the meaning, they look up the word in their dictionaries.

- The teacher reads the text again.

- Then students do the related exercises.

The length of the course was the same for both the experimental and the control groups. In the last session, all the students in two groups again completed the self-regulation questionnaire (MSLQ).

\section{Findings And Discussion}

Probing the aforementioned research question and following the planned procedure, different descriptive and inferential statistics were used to analyze the obtained data.

\subsection{Descriptive Statistics of the PET Proficiency Test Piloting}

As mentioned before, the PET consisted of 67 items was administered to a group of 30 intermediatelevel EFL learners at the same language school bearing almost the same characteristics as the target sample. Table 2 shows the descriptive statistics of the PET in the piloting phase.

Table 2: Descriptive Statistics of the PET Piloting

\begin{tabular}{|l|c|c|c|c|c|c|}
\hline & $\mathrm{N}$ & Minimum & Maximum & Mean & Std. Deviation & Variance \\
\hline VAR00006 & 30 & 53.00 & 91.00 & 72.5200 & 8.16669 & 81.483 \\
Valid N (listwise) & 30 & & & & & \\
\hline
\end{tabular}

Table 3 shows the reliability of the test scores gained from the participants in the PET piloting phase.

Table 3: Reliability of the PET Piloting before Deletion of Malfunctioning Items

\begin{tabular}{|c|c|}
\hline Cronbach's Alpha & N of Items \\
\hline .901 & 67 \\
\hline
\end{tabular}

After deletion of the 2 malfunctioning items, the reliability of the test shifted to .936 . Table 4 shows the reliability of the test scores after the deletion.

Table 4: Reliability of the PET Piloting after Deletion of Two Malfunctioning Items

\begin{tabular}{|c|c|}
\hline Cronbach's Alpha & N of Items \\
\hline .936 & 65 \\
\hline
\end{tabular}

In addition, there were two writing tasks and a speaking part in the test rated by two raters (two of the researchers) using the predetermined PET rating scales. In order to calculate the inter-rater reliability between the raters, the researchers used the Pearson Correlation Coefficient. The results showed that there was a significant correlation between the two raters. Therefore, this gave assurance to the researchers that the same raters can be used for the actual administration of the test. Tables 5 to 7 show the results.

Table 5: Inter-rater Reliability of the Two Raters in the Piloting of Writing Part 2

\begin{tabular}{|l|l|c|c|}
\hline \multicolumn{2}{|c|}{} & VAR00001 & VAR00002 \\
\hline VAR00001 & Pearson Correlation & 1 & $.899^{* *}$ \\
\cline { 2 - 4 } & Sig. (2-tailed) & & .000 \\
\cline { 2 - 4 } & $\mathrm{N}$ & 30 & 30 \\
\hline \multirow{3}{*}{ VAR00002 } & Pearson Correlation & $.877^{* *}$ & 1 \\
\cline { 2 - 4 } & Sig. (2-tailed) & .000 & 30 \\
\cline { 2 - 4 } & $\mathrm{N}$ & 30 & 30 \\
\hline
\end{tabular}


**. Correlation is significant at the 0.01 level (2-tailed).

Table 6: Inter-rater Reliability of the Two Raters in the Piloting of Writing Part 3

\begin{tabular}{|ll|c|c|}
\hline & & VAR00003 & VAR00004 \\
\hline \multirow{5}{*}{ VAR00003 } & Pearson Correlation & 1 & $.742^{* *}$ \\
& Sig. (2-tailed) & & .000 \\
& $\mathrm{~N}$ & 30 & 30 \\
& Pearson Correlation & $.723^{* *}$ & 1 \\
VAR00004 & Sig. (2-tailed) & .000 & \\
& $\mathrm{~N}$ & 30 & 30 \\
\hline
\end{tabular}

**. Correlation is significant at the 0.01 level (2-tailed).

Table 7: Inter-rater Reliability of the Two Raters in the Piloting of Speaking

\begin{tabular}{|ll|c|c|}
\hline \multirow{4}{*}{ VAR00005 } & Pearson Correlation & 1 & $.789^{* *}$ \\
& Sig. (2-tailed) & & .000 \\
& $\mathrm{~N}$ & 30 & 30 \\
& Pearson Correlation & $.778^{* *}$ & 1 \\
VAR00006 & Sig. (2-tailed) & .000 & \\
& $\mathrm{~N}$ & 30 & 30 \\
\hline
\end{tabular}

**. Correlation is significant at the 0.01 level (2-tailed).

\subsection{Descriptive Statistics of the PET Proficiency Test Administration}

After the procedure of piloting the PET, it became an instrument to homogenize the students for this study. On the whole, 90 students participated in the test administration. After the administration of the test, descriptive statistics were calculated just as were done in the piloting phase. Table 8 and Table 9 show the results.

Table 8: Descriptive Statistics of the PET Administration

\begin{tabular}{|l|c|c|c|c|c|}
\hline & $\mathrm{N}$ & Minimum & Maximum & Mean & Std. Deviation \\
\hline VAR00007 & 90 & 54.00 & 91.00 & 74.223 & 7.5643 \\
Valid N (listwise) & 90 & & & & \\
\hline
\end{tabular}

Table 9: Reliability of the PET Administration

\begin{tabular}{|c|c|}
\hline Cronbach's Alpha & N of Items \\
\hline .942 & 65 \\
\hline
\end{tabular}

\subsection{Descriptive Statistics of the Self-Regulation Scores}

From among the 90 students who took the piloted PET, 60 of them whose scores fell between one standard deviation below and above the mean were divided randomly into two experimental and control groups.

All of the students in the four groups completed the MSLQ self-regulation questionnaire, (Pintrich, et al., 1991) ${ }^{[33]}$, as the pretest and post-test in order to make sure that there was no significant difference between the two groups regarding the self-regulation variable before the treatment. For that purpose a $t$-test was needed. But prior to that, four assumptions of independence of subjects, interval data, normality, and homogeneity should be met before one decides to run parametric tests (Field, 2009) ${ }^{[40]}$.

The present data are measured on an interval scale and the subjects perform independently on the tests. As displayed in Table 10 the ratios of skewness and kurtosis over their respective standard errors are within the ranges of $+/-1.96$, hence the normality assumption of the distribution is also met.

Table 10: Descriptive Statistics of the Self-Regulation Scores

\begin{tabular}{|c|c|c|c|c|c|c|c|c|}
\hline \multicolumn{2}{|c}{ Group } & $\mathrm{N}$ & \multicolumn{3}{c|}{ Skewness } & \multicolumn{3}{c|}{ Kurtosis } \\
\cline { 3 - 10 } & Statistic & Statistic & Std. Error & Ratio & Statistic & Std. Error & Ratio \\
\hline \multirow{2}{*}{ Experimental } & Pretest & 30 & -.010 & .427 & -0.023 & -.975 & .833 & -1.170 \\
\cline { 2 - 11 } & Post-test & 30 & .325 & .427 & 0.761 & -1.393 & .833 & -1.672 \\
\hline
\end{tabular}




\begin{tabular}{|c|c|c|c|c|c|c|c|c|}
\hline \multirow{2}{*}{ Control } & Pretest & 30 & .335 & .427 & 0.785 & -.882 & .833 & -1.059 \\
\hline & Post-test & 30 & .645 & .427 & 1.511 & -.997 & .833 & -1.197 \\
\hline
\end{tabular}

The assumption of homogeneity of variances will be checked when reporting the results of the independent $t$-test.

\subsubsection{Self-Regulation Pre-test}

An independent $t$-test is run to compare the experimental and control groups' mean scores on selfregulation pretest in order to prove that the two groups enjoyed the same level of self-regulation prior to the treatment. As displayed in Table 11 the mean scores for experimental and control groups on self-regulation pretest are 158.47 and 157.50 respectively.

Table 11: Descriptive Statistics of Self-Regulation Pretest by Experimental \& Control Groups

\begin{tabular}{|l|c|c|c|c|}
\hline & $\mathrm{N}$ & Mean & Std. Deviation & Std. Error Mean \\
\hline Experimental & 30 & 158.47 & 3.730 & .681 \\
\hline Control & 30 & 157.50 & 3.884 & .709 \\
\hline
\end{tabular}

The results of the independent $t$-test $(\mathrm{t}(58)=.98, \mathrm{P}=.33>.05, \mathrm{r}=.12$ it represents a weak effect size) indicate that there was not any significant difference between experimental and control groups' mean scores on the self-regulation pretest. Thus it can be concluded that the two groups enjoyed the same level of selfregulation prior to the treatment (Table 12).

Table 12: Independent $t$-test of Self-Regulation Pretest by Experimental \& Control Groups

\begin{tabular}{|c|c|c|c|c|c|c|c|c|c|}
\hline & \multicolumn{2}{|c|}{$\begin{array}{c}\text { Levene's Test for } \\
\text { Equality of Variances }\end{array}$} & \multicolumn{7}{|c|}{ t-test for Equality of Means } \\
\hline & \multirow[t]{2}{*}{$\mathrm{F}$} & \multirow[t]{2}{*}{ Sig. } & \multirow[t]{2}{*}{$\mathrm{T}$} & \multirow[t]{2}{*}{ Df } & \multirow[t]{2}{*}{$\begin{array}{l}\text { Sig. (2- } \\
\text { tailed) }\end{array}$} & \multirow[t]{2}{*}{$\begin{array}{c}\text { Mean } \\
\text { Difference }\end{array}$} & \multirow[t]{2}{*}{$\begin{array}{l}\text { Std. Error } \\
\text { Difference }\end{array}$} & \multicolumn{2}{|c|}{$\begin{array}{l}95 \% \text { Confidence } \\
\text { Interval of the } \\
\text { Difference }\end{array}$} \\
\hline & & & & & & & & Lower & Upper \\
\hline $\begin{array}{l}\text { Equal variances } \\
\text { assumed }\end{array}$ & .145 & .705 & .983 & 58 & .330 & .967 & .983 & -1.001 & 2.935 \\
\hline $\begin{array}{l}\text { Equal variances } \\
\text { not assumed }\end{array}$ & & & .983 & 57.905 & .330 & .967 & .983 & -1.001 & 2.935 \\
\hline
\end{tabular}

It should be noted that the assumption of homogeneity of variances is met (Levene's $\mathrm{F}=.145, \mathrm{P}=.705$ $>.05)$. That is why the first row of Table 12, i.e. "Equal variances assumed" is reported. Figure 1 also shows the obtained results.

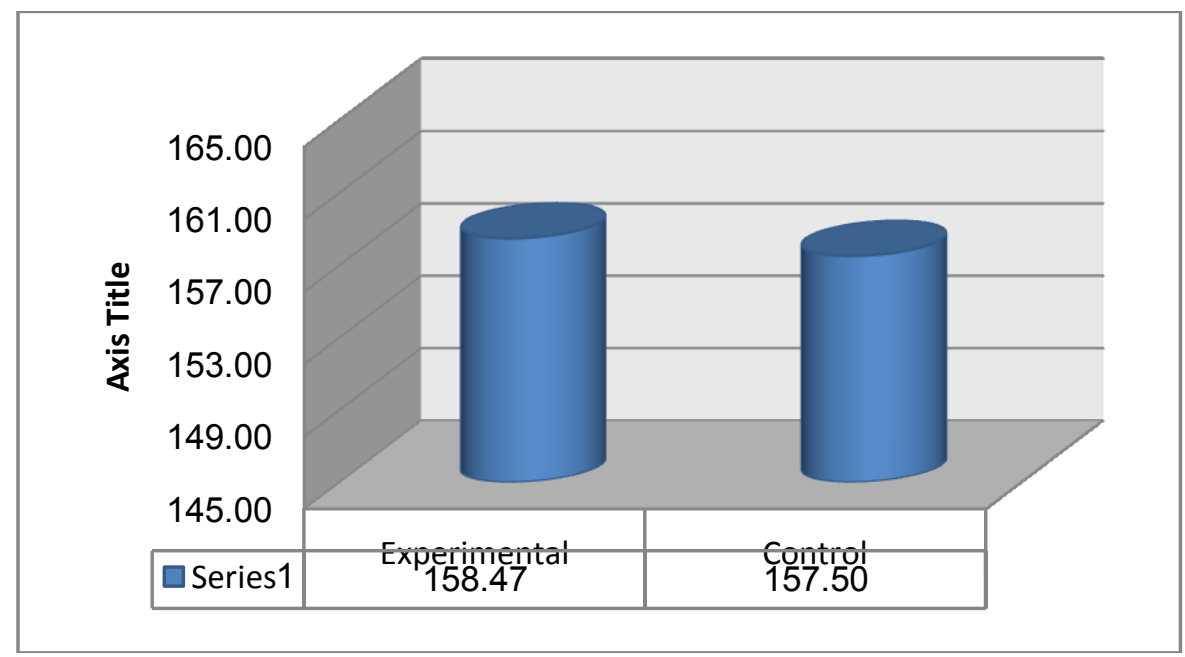

Figure 1: Self-Regulation Pretest by Experimental \& Control Groups 


\subsection{Research Question}

An independent $t$-test is run to compare the experimental and control groups' mean scores on selfregulation post-test in order to probe the effect of teaching concept mapping strategy in reading on EFL learners' self-regulation. As displayed in Table 13 the mean scores for experimental and control groups on self-regulation post-test are 237.10 and 163.77 respectively.

Table 13: Descriptive Statistics of Self-Regulation Post-test by Experimental \& Control Groups

\begin{tabular}{|l|c|c|c|c|}
\hline Group & $\mathrm{N}$ & Mean & Std. Deviation & Std. Error Mean \\
\hline Experimental & 30 & 237.10 & 32.878 & 6.003 \\
\hline Control & 30 & 163.77 & 5.600 & 1.022 \\
\hline
\end{tabular}

The results of the independent $t$-test $(\mathrm{t}(58)=12.04, \mathrm{P}=.000<.05, \mathrm{r}=.90$ it represents a large effect size) indicate that there is a significant difference between experimental and control groups' mean scores on the post-test of self-regulation. Thus, in response to the research question, it can be concluded that teaching concept mapping strategy in reading have a statistically significant effect on EFL learners' self-regulation. This means that the experimental group after receiving concept mapping strategy outperformed the control group on the self-regulation post-test (Table 14, and Figure 2).

Table 14: Independent $t$-test of Self-Regulation Post-test by Experimental \& Control Groups

\begin{tabular}{|c|c|c|c|c|c|c|c|c|c|}
\hline & \multicolumn{2}{|c|}{$\begin{array}{c}\text { Levene's Test for } \\
\text { Equality of Variances }\end{array}$} & \multicolumn{7}{|c|}{ t-test for Equality of Means } \\
\hline & \multirow[t]{2}{*}{$\mathrm{F}$} & \multirow[t]{2}{*}{ Sig. } & \multirow[t]{2}{*}{$\mathrm{T}$} & \multirow[t]{2}{*}{ Df } & \multirow{2}{*}{$\begin{array}{l}\text { Sig. } \\
(2- \\
\text { tailed })\end{array}$} & \multirow[t]{2}{*}{$\begin{array}{c}\text { Mean } \\
\text { Difference }\end{array}$} & \multirow[t]{2}{*}{$\begin{array}{l}\text { Std. Error } \\
\text { Difference }\end{array}$} & \multicolumn{2}{|c|}{$\begin{array}{l}95 \% \text { Confidence } \\
\text { Interval of the } \\
\text { Difference }\end{array}$} \\
\hline & & & & & & & & Lower & Upper \\
\hline $\begin{array}{ll}\text { Equal variances } \\
\text { assumed }\end{array}$ & 70.646 & .000 & 12.043 & 58 & .000 & 73.333 & 6.089 & 61.144 & 85.522 \\
\hline $\begin{array}{l}\text { Equal variances not } \\
\text { assumed }\end{array}$ & & & 12.043 & 30.681 & .000 & 73.333 & 6.089 & 60.909 & 85.758 \\
\hline
\end{tabular}

Figure 2 also shows the obtained results.

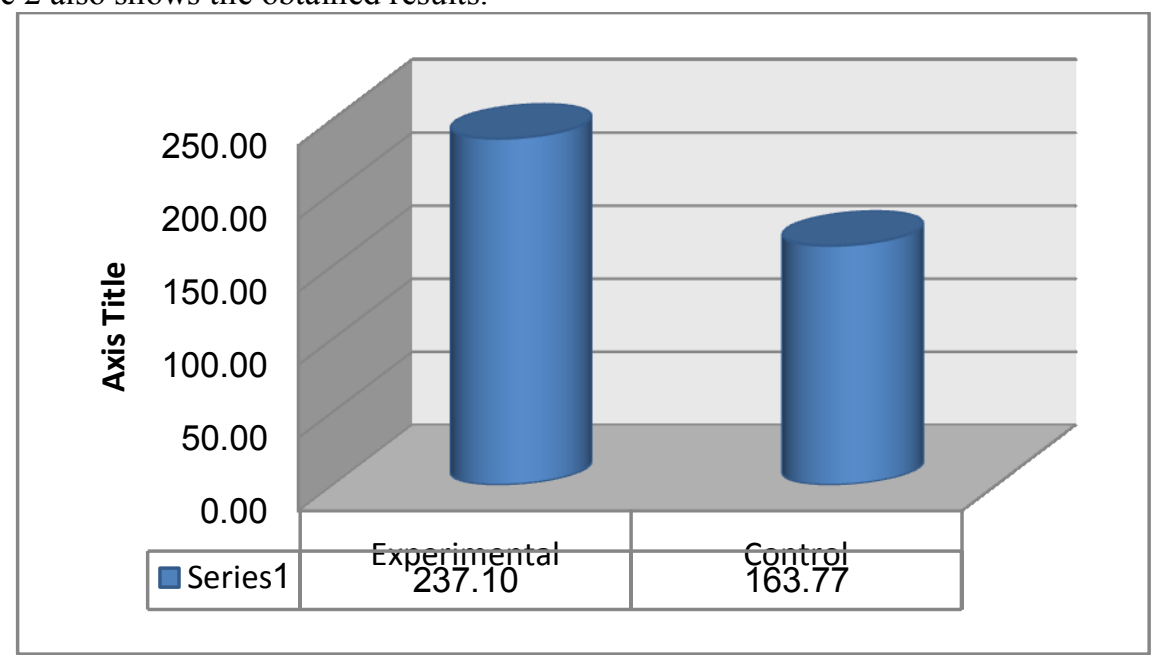

Figure 2: Self-Regulation Post-test by Experimental and Control Groups

\subsection{Discussion}

The results of the present study showed a significant effect of the explicit instruction of the concept mapping strategy in reading on EFL intermediate learners' self-regulation. This outcome is consistent with the findings of Ley and Young (1998) ${ }^{[41]}$ in that instruction in strategy use is an effective means of promoting selfregulation. Also, Zimmerman and Paulsen (1995) ${ }^{[42]}$ found that organizing is a key component of selfregulation. Moreover, it confirms the findings of Hofer, $\mathrm{Yu}$, and Pintrich (1998) ${ }^{[4]}$ in that organizational strategies, such as outlining content or relating concepts within content, are among the cognitive learning strategies that individuals use to self-regulate.

Another explanation might be that, as Barnhardt (1997) ${ }^{[44]}$ stated, there is a relationship between strategy use and confidence in language learning. For students who have had difficulties in reading comprehension of a foreign language, a positive change in attitude due to their success in the application of the concept mapping strategy might be the initial step toward improved self-regulation. It meant that when the 
students had a better idea of how to organize the concepts in reading task, they were more positive about the task. In other words, concept mapping strategy helped students attend to reading comprehension tasks, and control their learning more effectively. This created a much more tangible evidence of the quality of both the learning process and concept understanding.

Also, the construction of concept maps might have helped students to build more complex cognitive structures regarding information which was vital for comprehension. According to Pintrich (2000) ${ }^{[30]}$, the cognitive area of self-regulation begins with goal setting, prior knowledge activation and planning. He places the actual use of cognitive strategies in the phase of cognitive control and regulation. It has been suggested that strategy instruction should be integrated into a larger framework of self-regulation involving the helping of students to identify their goals in a learning task (Butler, 2002) ${ }^{[45]}$. Butler (2002) ${ }^{[45]}$ added that by strategy intervention it is easier to demonstrate the different types of knowledge which are essential for fostering students' self-regulated strategy use.

Improved self-regulation due to the positive effect of concept mapping strategy is explained by McAleese (1998) ${ }^{[11]}$ in that individuals are affected by control mechanisms that are both external and internal. $\mathrm{He}$ also added that, there is some interaction between the external representation (concept mapping) and the internal understanding (self-regulation). The factors that determine students' behavior shift between the internal self-regulation and the external factor of concept mapping.

\section{Conclusion}

The outcome of the statistical analysis clarified that the explicit instruction of concept mapping in reading has a significant impact on EFL learners' self-regulation. That is to say, teaching concept mapping significantly increased learners' self-regulation. In fact, the benefits of concept mapping might extend beyond achievement gains to some variables such as self-regulation which is an achievement-related variable (Talebinezhad \& Mousapour Negari, 2009) ${ }^{[27]}$. As an implication, it seems that the use of concept mapping strategy in the courses of reading could be as a means of constructing knowledge and promoting self-regulation.

\section{References}

[1] Chastain, K. (1988). Developing second language skills: Theory and practice (3rd ed.). New York: Harcourt Brace Jovanovich.

[2] Huang, L. I. (2005). Using concept mapping as a strategy to improve the English reading comprehension. Unpublished master's thesis, Tzu Chi University, Hualian City, Taiwan.

[3] Nunan, D. (1999). Second language teaching and learning. Boston: Heinle \& Heinle.

[4] Park, S. (1995). Implications of learning strategy research for designing computer-assisted instruction. Journal of Research on Computing in Education, 27 (4), 435-456.

[5] O’Malley, J. M., Chamot, A. U., \& Stewner-Manzanares, Kupper, G. L \& Russo R. (1985). Learning strategies used by beginning and intermediate ESL students, Language Learning, 35(1), 21-46.

[6] Anderson, N. (1991). Individual differences in strategy use in second language reading and testing. Modern language Journal, 75, 460-472.

[7] Hauck, M. (2005). Metacognitive knowledge, metacognitive strategies, and CALL. In J. Egbert \& G. Petrie (Eds.), CALL: Research Perspectives (pp. 65-86). New Jersey: Lawrence Erlbaum.

[8] Pressley, M. (1982). Elaboration and memory development. Child Development, 53, 296-309.

[9] Weinstein, C. E. (1988). Elaboration skills as a learning strategy. New York: Academic Press.

[10] Mintzes, J. J., Wandersee, J. H., \& Novak, J. D. (1997). Meaningful learning in science: The human constructivist perspective. In G. D. Phye (Ed.), Handbook of academic learning: Construction of Knowledge (pp. 405-447). San Diego: Academic Press.

[11] McAleese, R. (1998). The knowledge arena as an extension to the concept map; reflection in action. Interactive Learning Environments, 6(3), 251-272.

[12] Brown, A. L. (1987). Metacognition, executive control, self-regulation, and other more mysterious mechanisms. In F.E. Weinert \& R.H. Kluwe (Eds.), Metacognition, motivation, and understanding (pp. 65-116). Hillsdale, NJ: Erlbaum.

[13] Novak, J. D. (1981). Applying learning psychology and philosophy of science to biology teaching. The American Biology Teacher, 43(1), 12-20.

[14] Block, E. (1986). The comprehension strategies of second language readers. TESOL Quarterly, 20, $463-494$.

[15] Carrell, P., Pharis, B. G., \& Liberto, J. C. (1989). Metacognitive strategy training for ESL reading. TESOL Quarterly, 23(4), 647673.

[16] Kamhi-Stein, L. (1993). Summarization, note taking, and mapping techniques: Lessons for L2 reading instruction. (ERIC Document Reproduction Service No. ED 306 816).

[17] Koumy, E., \& Salam, A. (1999). Effects of three semantic mapping strategies on EFL Students' reading comprehension. (ERIC Document Reproduction Service No. ED 435 193).

[18] Heinze-Fry, J., \& Novak, J. (1990). Concept mapping brings long-term movement toward meaningful learning. Science Education, $74,461-472$.

[19] Cassata-Widera, A. E. (2008). Concept mapping and early literacy: A promising crossroads. In A. J. Caoas, P. Reiska, M. Ehlberg, \& J. D. Novak (Eds.), Concept Mapping: Connecting Educators (pp. 123-131). Finland, Tallinn: Estonia \& Helsinki.

[20] Chimielewski, T., \& Dansereau, D. (1998). Enhancing the recall of text: Knowledge mapping training promotes implicit transfer. Journal of Educational Psychology, 90(3), 407-413.

[21] Griffin, C. C., Malone, L. D., \& Kameenui, E. J. (1995). Effects of graphic organizer instruction on fifth-grade students. The Journal of Educational Research, 89, 98-107.

[22] Liou, H.C. (2006). The effectiveness of concept mapping instruction on summarization learning for elementary school sixth graders. Unpublished masters' thesis, National Hualien University of Education, Hualien, Taiwan. 
[23] Robinson, D. H., Katayama, A. D., \& Fan, A. (1996). Evidence for conjoint retention encoded from spatial adjunct displays. Contemporary Educational Psychology, 21, 221-239.

[24] Zittle, F., Johari, A., \& Eastmond, D. (2005). The ASTD E-learning handbook: Best practices, strategies and case studies for an emerging field. Quarterly Review of Distance Education, 6(1), 65-71.

[25] Cubukcu, K. M. (2009). Evaluating higher education policy in Turkey: Assessment of the admission procedure to architecture, planning and engineering schools. International Journal of Education Policy and Leadership, 4 (4), 1-13.

[26] Ryan, R. M., Deci, E. L., Grolnick, W. S., \& LaGuardia, J. G. (2006). The significance of autonomy and autonomy support in psychological development and psychopathology. In D. Cicchetti \& D. Cohen (Eds.) Developmental Psychopathology: Volume 1, Theory and Methods (2nd Edition, pp. 295-849). New York: John Wiley \& Sons.

[27] Talebinezhad, M. R. \& G. Mousapour Negari, (2009). The effect of explicit teaching of concept mapping in expository writing on EFL students' self-regulation. Pazhuhesh-e Zabanha-ye Khareji, 49, 85-108.

[28] Bandura, A. (1980). Gauging the relationship between self-efficacy judgment and action. Cognitive Therapy and Research, 4, 263268.

[29] Zimmerman, B. J. (1986). Development of self-regulated learning: Which are the key subprocesses? Contemporary Educational Psychology, 11, 307-313.

[30] Pintrich, P. R. (2000). The role of goal orientation in self-regulated learning. In M. Boekaerts, P. Pintrich, \& M. Zeidner (Eds.), Handbook of self-regulation, research, and applications (pp. 451-502). Orlando, FL: Academic Press.

[31] Zimmerman, B. J. (2001). Theories of self-regulated learning and academic achievement: An overview and analysis. In B. J. Zimmerman, \& D. H. Schunk (Eds.), Self-regulated learning and academic achievement: Theoretical perspectives (2nd ed., pp. 137). Mahwah, NJ: Erlbaum.

[32] Oxford, R. L. (1990). Language learning strategies: What every teacher should know. New York: Newbury House.

[33] Pintrich, P. R., D. A. Smith, T. Garcia, \& W. J. McKeachie. (1991). A manual for the use of the Motivated Strategies for Learning Questionnaire (MSLQ). National Center for Research to Improve Postsecondary Teaching and Learning. Ann Arbor: University of Michigan.

[34] D’Apollonia, S., Galley, D., \& Simpson, M. (2001). Formal reasoning and conceptual development. Retrieved March 21 , 2011 from: http://www.place.dawsoncollege.qc.ca/ sdapoll/PAREA96.htm.

[35] Barker, J. R., \& Olsen, J. P. (2002). Medical students learning strategies: Evaluation of first-year changes. University of Mississippi Medical Centre, Department of Institutional Research, Jackson MS 39216-4505.

[36] Garcia, T., \& Pintrich, P. R. (1994). Regulating motivation and cognition in classroom. In D. H. Schunk, \& B. J. Zimmerman (Eds.), Self-regulation of learning and performance (pp. 127-154). Hillsdale, NJ: Erlbaum.

[37] Navidi, A. (2003). The significant Study of common and special of former academic function variables academic self-concept and general intelligence in academic achievement prediction of students. The Quarterly Journal of Education , 76, 97-129.

[38] Harris, K. R., \& Graham, S. (1996). Making the writing process work: Strategies for composition and self-regulation. Cambridge, MA: Brookline.

[39] Soars, L., Soars, J. (2005). American Headway 4. Oxford: Oxford University Press.

[40] Field, A. (2009). Dicovering Statistics Using SPSS. London: Sage Publications.

[41] Ley, K., \& D.B. Young. (1998). Self-regulation behaviours in underprepared (developmental) and regular admission college students. Contemporary Educational Psychology 23, 42-64.

[42] Zimmerman B. J. and A. S. Paulsen. (1995). Self-monitoring during collegiate studying: An invaluable tool for academic selfregulation. In P. R. Pintrich (Ed.), Understanding self-regulated learning (pp. 13-28). San Francisco: Jossey Bass.

[43] Hofer, B., Yu, S. L., \& Pintrich, P. R. (1998). Teaching college students to be self-regulated learners. In D. H. Schunk \& B. J. Zimmerman (Eds.), Self-regulated learning: From teaching to self-reflective practice (pp. 57-85). New York: Guilford.

[44] Barnhardt, S. (1997). Self-efficacy and second language learning. The NCLRC Language Resource, 1(5).

[45] Butler, D. L. (2002). Individualizing instruction in self-regulated learning. Theory into practice, 41, 81-92. 